\title{
ВПРОВАДЖЕННЯ ЦИФРОВИХ ОСВІТНІХ ТЕХНОЛОГІЙ У ПІДГОТОВКУ МАЙБУТНІХ УЧИТЕЛІВ В УМОВАХ ДИСТАНЦІЙНОГО НАВЧАННЯ
}

У статті розглядається основні аспекти впровадження цифррових освітніх технологій у навчальний проиес підготовки майбутніх учителів та проблеми використання циифрових технологій у сучасній вищій школі, зокрема в умовах дистанційного навчання. Стрімкий розвиток інформачійних технологій підвищив актуальність модернізаиії системи безперервної освіти. Одним із пріоритетних напрямів програми модернізації загальноосвітньої і вищчої школи визнане дистанційне навчання. Для сучасного періоду є характерним прогрес иифрової науки, реформування освіти, впровадження інноваційних технологій, тому актуальними наразі є пошуки таких стратегій навчання, які пов'язані як з ефективним використанням інформаційних $і$ комунікаційних технологій, так $і$ навчанням та вихованням молодої, креативної $i$ творчої особистості у будь-який час $i$ у будь-якому місųi. На основі аналізу стану та перспектив впровадження комп'ютерних інформаційних технологій у систему освіти виокремлено аспекти використання ичифрових технологій у дистанційному навчанні. Варто відзначити щчо, дистаниійне навчання в сучасному світі здійснюється за допомогою різноманітних технологій, які відрізняються за: формою подання навчальних матеріалів; наявністю посередника в системі навчання або за иеентралізованою формою навчання. Саме у статті досліджуються особливості впровадження циифрових освітніх технологї Google Classroom - хмарної безкоштовної інтерактивної платформи, використання якої не потребує додаткового програмного забезпечення для дистаниійного навчання. Відзначимо, щзо в цифрових освітніх середовищах поведінка обох суб'єктів змінюється, відбувається перерозподіл ролей викладача та студента. У статті проаналізовано можливості застосування сервісу Google Classroom для дистаниійного навчання та відмічено щзо такий підхід змушує викладача творчо підходити до викладання дисципліни та бути завжди он-лайн для комунікації зі студентами.

Ключові слова: хмарні технологї, дистанційне навчання, циифрові освітні технологї̈, підготовка вчителя, інформаційне суспільство. 


\title{
Borys SHEVCHUK, orcid.org/0000-0002-4406-1011 Candidate of Pedagogical Sciences, Associate Professor at the Department of Digital Learning Technologies Hryhoriy Skovoroda University in Pereyaslav (Pereyaslav, Kyiv region, Ukraine) sh.bera04@gmail.com
}

\author{
Larysa SHEVCHUK, \\ orcid.org/0000-0002-8405-1168 \\ Candidate of Pedagogical Sciences, Associate Professor, \\ Associate Professor at the Department of Mathematics, Informatics and Teaching Methods \\ Hryhoriy Skovoroda University in Pereyaslav \\ (Pereyaslav, Kyiv region, Ukraine) sheld65l@gmail.com
}

\section{INTRODUCTION OF DIGITAL EDUCATIONAL TECHNOLOGIES IN TRAINING OF FUTURE TEACHERS IN THE CONDITIONS OF DISTANCE LEARNING}

The article considers the main aspects of the introduction of digital educational technologies in the educational process of training future teachers and the problems of using digital technologies in modern higher education, in particular in the context of distance learning. The rapid development of information technology has increased the urgency of modernizing the system of continuing education. One of the priority areas of the modernization program of secondary and higher schools is distance learning. The modern period is characterized by the progress of digital science, education reform, introduction of innovative technologies, so the current search for such learning strategies, which are associated with the effective use of information and communication technologies and training and education of young, creative and creative personality in anytime and anywhere. Based on the analysis of the state and prospects of the introduction of computer information technologies in the education system, aspects of the use of digital technologies in distance learning have been identified. It is worth noting that distance learning in the modern world is carried out using a variety of technologies that differ in: the form of presentation of educational materials; the presence of an intermediary in the training system or a centralized form of training. The article explores the features of the introduction of digital educational technology Google Classroom - a cloud-based free interactive platform, the use of which does not require additional software for distance learning. Note that in digital educational environments, the behavior of both subjects is changing, there is a redistribution of roles of teacher and student. The article analyzes the possibilities of using the Google Classroom service for distance learning and notes that this approach forces the teacher to be creative in teaching the discipline and always be online to communicate with students.

Key words: cloud technologies, distance learning, digital educational technologies, teacher training, information society.

Постановка проблеми. Важливою особливістю сучасного періоду розвитку суспільства $\epsilon$ його інформатизація, яка на сучасному етапі розвитку набуває все більш глобального характеру, що веде до формування і становлення на нашій планеті інформаційного суспільства. Неодмінною умовою інформатизації суспільства є інформатизація освіти, мета якої полягає в радикальному підвищенні ефективності та якості підготовки фахівців на основі широкого використання нових інформаційно-комунікаційних технологій навчання, підготовці підростаючого покоління до життя в інформаційному суспільстві. Стрімкий розвиток інформаційних технологій підвищив актуальність модернізації системи безперервної освіти. Одним з пріоритетних напрямів програми модернізації загальноосвітньої і вищої школи визнане дистанційне навчання. В сучасних умовах, існує потреба отримання вищої освіти дистанційно, що викликано необхідністю навчатися без відриву від виробництва, отримання освіти людьми з обмеженими можливостями та тими, що перебувають за кордоном або у відрядженні. Таку можливість надає дистанційне навчання, яке здійснюється завдяки цифровим освітнім технологіям і системам комунікації (Хатаева, 2014).

Аналіз досліджень (Ггнатенко, 2016; Карєвік, 2010; Вишнівський, Гніденко, Гайдур, Ільїн, 2014) свідчить про значну увагу до впровадження інноваційних технології у навчальний процес ЗВО. С. Архангельський, Г. Атанов, Г. Гергей, Б. Гершунський, Є. Машбиць, Н. Тверезовська i багато інших вітчизняних і зарубіжних авторів пов'язували питання оптимізації процесу навчання 3 використанням у ньому сучасних комп'ютерних технологій (Ковальська, 2009). Дослідженням науково-педагогічних засад дистанційного навчання займаються такі науковці, як В. Кухаренко, В. Олійник, В. Рибалко, Н. Сиротенко, П. Стефаненко, А. Хуторський, питання 
організації дистанційної форми навчання у вищих навчальних закладах розглядали Р. Вернидуб, Л. Головко, Л. Гурч, І. Дичківська, В. Ковальчук, Г. Ржевський, О. Третьякова та інші; організаційнометодичні особливості розробки та впровадження дистанційних курсів у процес професійної підготовки педагогів проаналізовано в працях Г. Алексєєвої, Л. Гаврілової, І. Костікової. Водночас, незважаючи на значну кількість різнопланових досліджень 3 дистанційної освіти, сьогодні практично відсутні наукові роботи, у яких би цілісно й усебічно розглядались застосування цифрових освітніх технологій при підготовці майбутніх учителів в умовах дистанційного навчання з урахуванням специфіки вищих навчальних закладів.

Метою статті $є$ дослідження особливостей впровадження цифрових освітніх технології у ЗВО в умовах дистанційного навчання.

Виклад основного матеріалу. Дистанційне навчання $є$ однією 3 нових реальностей сучасного освіти, яке докорінно відрізняється від традиційних форм навчання. При розгляді дистанційного навчання як діяльності, опосередкованої комп'ютерними технологіями, треба відзначити, що вона характеризується низкою психологічних особливостей в порівнянні 3 традиційними формами навчання (Ржевський, 2017).

Головною метою створення системи дистанційної освіти $\epsilon$ забезпечення загальнонаціонального доступу до освітніх ресурсів шляхом використання сучасних цифрових технологій та телекомунікаційних мереж і створення умов для реалізації громадянами своїх прав на освіту. Дистанційне навчання забезпечує можливість навчатися тоді, коли зручно студенту, у тому темпі, що він сам обирає (у межах установлених строків проведення курсів), в тому місці де він перебуває (не має потреби витрачати час на дорогу до ЗВО, для здачі поточних, а іноді і підсумкових контролів) (Ігнатенко, 2016 ).

Порівнюючи традиційне та дистанційне навчання Г. Ржевський виокремлює сновні відмінності та преваги дистанційного навчання (Ржевський, 2017):

- можливість займатися в зручний для себе час, у зручному місці і темпі;

- паралельне 3 професійною діяльністю навчання, тобто без відриву від виробництва;

- можливість звернення до багатьох джерел навчальної інформації (електронним бібліотекам, банкам даних, базам знань і т.п.);

- концентрований уявлення навчальної інформації та доступ до неї підвищує ефективність засвоєння матеріалу;
- використання в освітньому процесі новітніх досягнень інформаційних і телекомунікаційних технологій, що навчає і роботі з ними;

- однакові можливості одержання освіти незалежно від місця проживання, стану здоров'я, елітарності і матеріальної забезпеченості студента;

- експорт та імпорт світових досягнень на ринку освітніх послуг;

- дистанційне навчання розширює і оновлює роль викладача, який повинен координувати пізнавальний процес, постійно удосконалити викладаються ним курси, підвищувати творчу активність і кваліфікацію відповідно до нововведень і інновацій;

- позитивний вплив надає дистанційна освіта і на студента, підвищуючи його творчий і інтелектуальний потенціал за рахунок самоорганізації, прагнення до знань, уміння взаємодіяти 3 комп'ютерною технікою і самостійно приймати відповідальні рішення;

- якість дистанційної освіти не поступається в ідеалі якості очної форми одержання освіти, а поліпшується за рахунок залучення видатного кадрового професорсько-викладацького складу і використання в навчальному процесі найкращих навчально-методичних видань i контролюючих тестів 3 дисциплін.

Варто зазначити, що дистанційне навчання в сучасному світі здійснюється за допомогою різноманітних технологій, які відрізняються за: формою подання учбових матеріалів; наявністю посередника в системі навчання або за централізованою формою навчання; за ступенем використання телекомунікацій і персональних комп’ютерів; за технологією організації контролю учбового процесу; за ступенем впровадження в технології навчання звичайних методів ведення освітнього процесу; за методами ідентифікації студентів при складанні іспитів (Ткачук, Семеріков, Счкало, 2017).

Враховуючи інноваційний потенціал та студентоцентричний характер організації комбінованої освітньої взаємодії, на факультеті гуманітарноприродничої освіти та соціальних технологій Переяслав-Хмельницького державного педагогічного університету імені Григорія Сковороди змішане навчання впроваджується 3 використанням різних моделей на рівні окремих курсів 3 використанням платформи дистанційного навчання як Moodle, так i G Suite for Education.

3 огляду на доступність, зручність використання, інтерактивність та інтегративність G Suite for Education, стрімко набуває популярності. Вона $€$ яскравим прикладом комбінування функцій системи управління та підтримки навчального про- 
цесу, що дозволяє розглядати її в якості віртуального навчального середовища.

Одним із сервісів G Suite for Education $€$ Google Classroom - хмарна безкоштовна інтерактивна платформа, використання якої не потребує додаткового програмного забезпечення. У Google Classroom гармонійно інтегруються як основні сервіси та додатки Google. Google Classroom об'єднує в собі: Google Drive для створення і обміну завданнями, Google Docs, Sheets and Slides для написання, Gmail для спілкування i Google Calendar для розкладу.

Таким чином, Google Classroom містить можливості для створення електронних освітніх ресурсів.

Як вказують О. Ігнатенко та В. Перевозник електронні освітні ресурси - це основний компонент інформаційного освітнього середовища, який орієнтований на реалізацію освітнього процесу за допомогою інформаційно-комунікаційних технологій і на застосування нових методів і форм навчання, таких як: електронне навчання; мобільне навчання; мережеве навчання; автономне навчання; змішане навчання; спільне навчання (Ігнатенко, 2016).

На думку Н. Морзе та О. Глазунової, електронний навчальний курс - це комплекс електронних навчально-методичних матеріалів, створених для організації індивідуального та групового навчання 3 використанням дистанційних технологій, що базуються на інтернет-технологіях, відповідно до графіку навчального процесу вищого навчального закладу (Морзе, Глазунова, 2009).

М. Кадемія, розглядаючи інформаційно-комунікаційні технології навчання, вважає електронний навчальний ресурс дидактичною системою, в якій з метою створення умов для педагогічної активності, інформаційної взаємодії між викладачами та студентами інтегруються прикладні програмні продукти, бази даних, а також інші дидактичні засоби і методичні матеріали, що забезпечують та підтримують навчальний процес (Кадемія, 2009).

В. Ткачук, С. Семеріков, Ю. Счкало розглядають створення електронних навчально-методичних комплексів у мобільно орієнтованому середовищі навчання ЗВО. Вони вводять поняття «мобільно орієнтований ЕНМК» - реалізований у мобільно орієнтованому середовищі навчання 3ВО комплекс навчально-методичних матеріалів, що має визначену структуру та в повному обсязі забезпечує вивчення дисципліни (Ткачук, 2017).

Таким чином, істотною відмінністю ЕНМК від електронних освітніх ресурсів $є$ те, що поєднуючи в собі сукупність всіх форм і видів навчаль- ної діяльності, вони забезпечують якісно новий рівень навчання в електронному освітньому середовищі педагогічного вишу.

Залежно від технології реалізації в навчальному процесі використовується три основних типи ЕНМКД: кейс (К); автоматизована навчальна система (АНC); дистанційний курс 3 Webбазуванням (ДК).

Кейс - комплект навчально-методичних матеріалів, який чітко структурований і відповідним чином сформований у спеціальний набір як у паперовому, так й електронному форматі.

Автоматизована навчальна система - комплект навчально-методичних матеріалів, який реалізовано у вигляді комп'ютерної програми навчального призначення. Вона $є$ однорідною за програмною реалізацією, інтерфейсними і дидактичними прийомами комп'ютерною програмою. Автоматизована навчальна система - це авторська інструментальна оболонка, яка дозволяє викладачам створювати електронні навчально-методичні комплекси 3 дисциплін в рамках парадигм, що підтримуються даною системою.

Дистанційний курс 3 Web-базуванням - це мережевий дистанційний курс, який $є$ електронним навчально-методичним комплексом 3 дисципліни, реалізований у середовищі Internet або Intranet. Дистанційний курс має такі переваги: орієнтація на гіпертекстову структуру Webдокумента; доступ з будь-якого серверу в мережі Internet або локальної мережі Університету; можливість створення інтерактивних додатків; можливість інтегрування у Web-документ матеріалів різного виду - текстових, графічних, аудіо- та відео матеріалів (Полат, 2000).

Розглянемо більш детальніше дистанційний курс «Цифрові освітні технології» розроблений на безкоштовному хмарному сервісі компанії Google в Google Classroom. Метою цього курсу $\epsilon$ формування та розвиток у студентів системи інформатичних компетентностей, які забезпечують здатність майбутнього педагога ефективно здійснювати професійну діяльність, організовувати інформаційну взаємодію суб'єктів освітнього середовища 3 використанням цифрових освітніх ресурсів, вирішувати професійні проблеми в межах цифрового освітнього середовища закладу освіти та інформаційного суспільства.

Базові складники курсу (конспекти лекцій, навчальні посібники, завдання для підготовки до семінарів та самостійної роботи, методичні вказівки, матеріали поточного та підсумкового контролю, додаткові відкриті ресурси) доступні студентам онлайн. Відтак практикуми, творчо-пошукова 
Шевчук Б., Шевчук $\Lambda$. Впровадження цифрових освітніх технологій ...

робота, проектна діяльність студентів не обмежуються стінами навчальної аудиторії, а за потреби (наприклад, коли слухач відсутній на занятті або виконання завдання потребу більше часу) можуть проводитьсь віддалено.

Середовище, створене на базі цифрових технологій навчання, зокрема в середовищі Google Classroom, характеризується можливістю викладачів та студентів реалізовувати різні види взаємодії засобами цифрових ресурсів: чати, електронна пошта, презентації, що значно збагачує взаємодію суб'єктів освітнього середовища, а можливість працювати індивідуально, в притаманному темпі та у обраному місці, ставить сервіс Google Classroom на чільне місце серед засобів підго- товки майбутнього фахівця. На думку Р. Хатаєвої, використання цифрових ресурсів в освітньому процесі інформатичної підготовки майбутніх учителів робить їх навчання комфортним та найбільш ефективним (Хатаева, 2014). Як показує практичний досвід, відкритість ресурсу підвищує навчальну мотивацію студентів, адже наявність $\mathrm{i}$ доступність навчальних матеріалів створює позитивну емоційну атмосферу впевненості і довіри між суб'єктами освітнього процесу.

Важливою перевагою віртуальної кімнати Google Classroom $є$ легка навігація, зручний інтерфейс, що інтуїтивно зрозумілий студентам. Середовище вміщує широкий арсенал засобів, за допомогою яких користувачі можуть як демонструвати

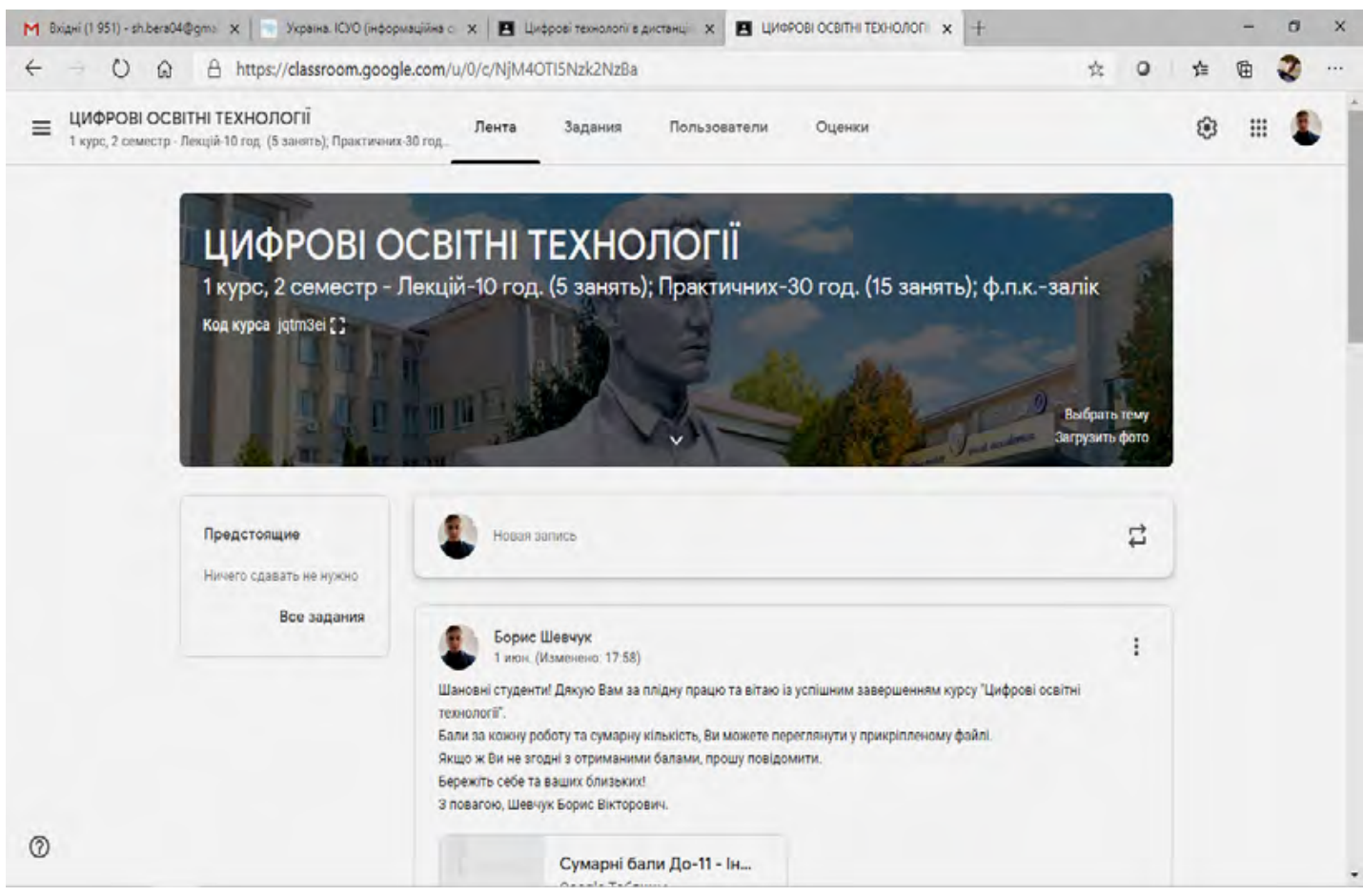

Рис. 1. Головне вікно дистанційний курс «Цифрові освітні технології» в середовищі Google Classroom

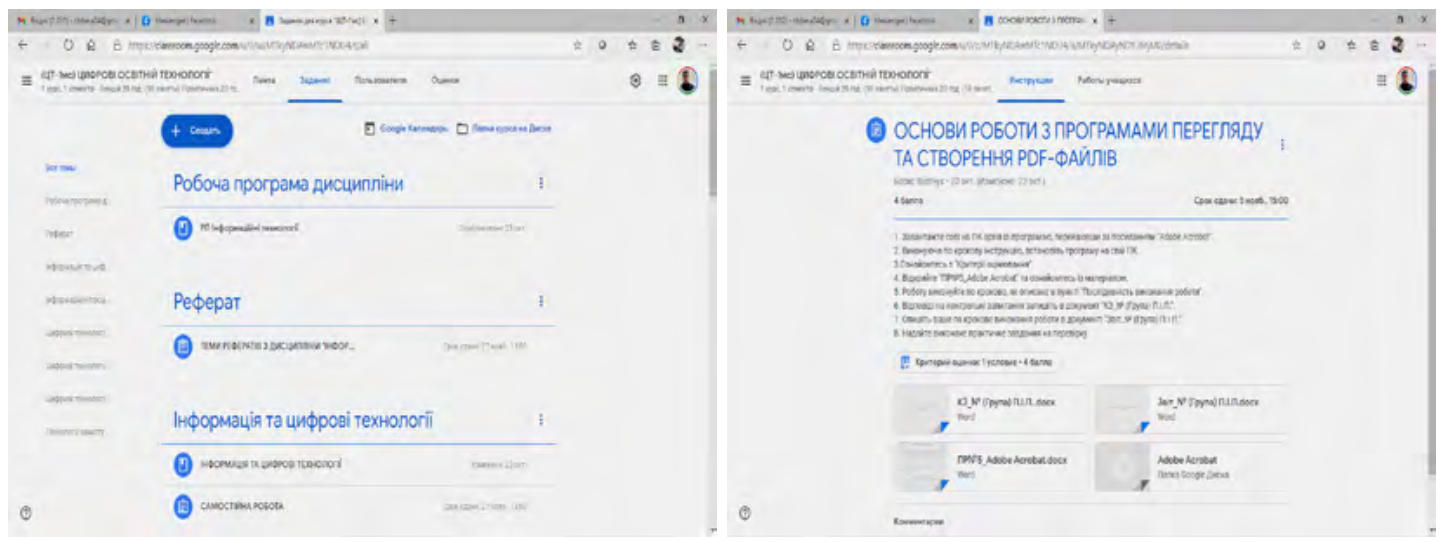

Рис. 2. Базові складники курсу «Цифрові освітні технології» в середовищі Google Classroom 
свої знання, так і обмінюватися ними, відслідковувати власний прогрес, отримувати своєчасну інформацію про нові події (наприклад, додавання нових елементів, сповіщення про оцінювання), ставити запитання, редагувати, коментувати, й оцінювати роботи інших, створювати як синхронні, так і асинхронні індивідуальні й групові проекти.

3 точки зору технологізації процесу навчання викладач не може вирішити задачі підвищення якості інформатичної підготовки майбутніх педагогів без викорис-

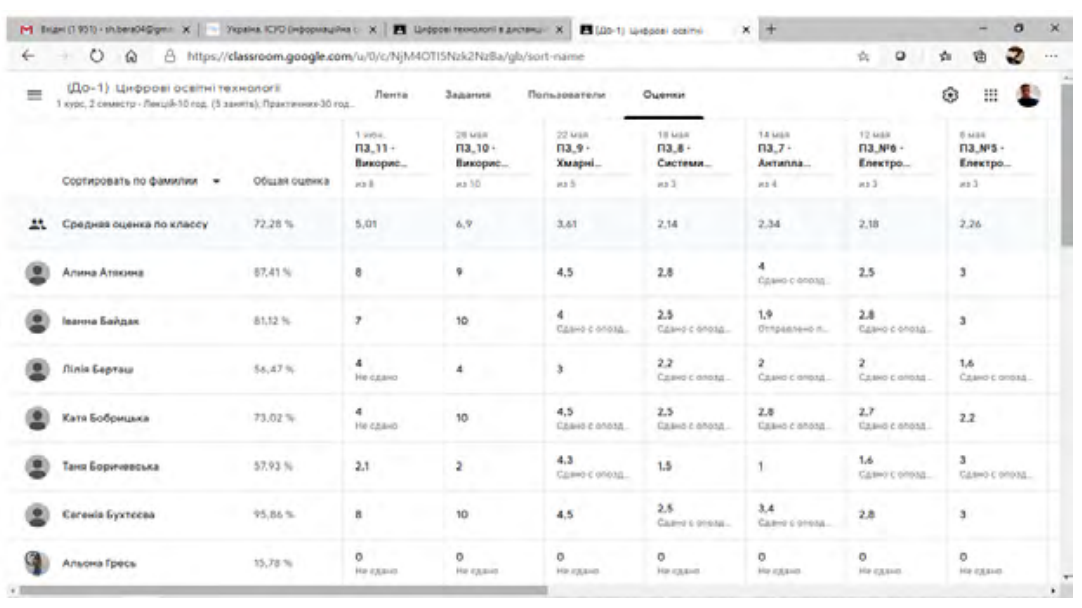

Рис. 3. Зведені оцінки курсу «Цифрові освітні технології» в середовищі Google Classroom

тання інноваційної техніки та засобів інформатизації, оскільки сучасний педагог зорієнтований на інноваційні методики навчання (Шевчук, 2017). 3 огляду на це, виникає необхідність переглянути вимоги до нових здатностей викладача у цифровому середовищі навчання. До них слід віднести: вміння комунікувати 3 використанням передових технологій, вміння навчати студентів 3 використанням цифрових технологій та в нових освітніх середовищах, вміння мотивувати студентів до електронного навчання, вміння спілкуватися 3 використанням цифрових технологій, включати студентів до процесу навчання 3 використанням цифрових on-line ресурсів, швидко встановлювати контакти в цифрових освітніх середовищах, адаптуватися до індивідуальних потреб студентів, бути інноваційним до використання передових технологій, адаптувати методи та засоби інноваційного навчання (Морзе, 2009). Необхідно відзначити, що в цифрових освітніх середовищах поведінка обох суб’ єктів змінюється, відбувається перерозподіл ролей викладача та студента. Викладач перестає бути постачальником, «ретранслятором» знань, а починає виконувати функції інструктора, посередника та наставника, що оперативно керує навчальним процесом. Діяльність викладача в цифрових освітніх середовищах навчання суттєво змінюється. Основне завдання викладача полягає в підготовці та удосконаленні електронного конспекту лекцій (ЕКЛ) на основі існуючих та нових матеріалів, які викладач удосконалює i розробляє, а також нових літературних джерел, розробці і використанні відкритих та дієвих методів для здобуття майбутніми педагогами професійних умінь і навичок (Полат, 2000). Відтак взаємодія викладача зі студентами 3 використанням віртуальної кімнати Google Classroom передбачає нову роль викладача-т'ютора, який, у свою чергу, виступає у декількох основних ролях: лектораексперта, організатора, консультанта. У кожній 3 них він організує взаємодію суб' єктів навчання в цифрових освітніх середовищах. У ролі лектора-експерта викладач розповідає новий матеріал, демонструє слайди, відповідає на питання учасників. У ролі організатора 3 використанням віртуальної кімнати Google Classroom викладач управляє навчально-пізнавальною діяльністю студентів, спрямовує взаємодію учасників практичного курсу та координує виконання завдань. Реалізація цього завдання здійснюється у двох напрямах: прямого педагогічного впливу або опосередкованого, яке закладено у логічну структуру ЕКЛ (інструкції, методичні вказівки, телеконференції та інші засоби зворотного зв'язку). У ролі консультанта викладач звертається до професійного досвіду студентів, спонукає їх самостійно збирати нові дані, шукати рішення вже поставлених задач та ставити нові (Карєвік, 2010).

При створенні завдань у віртуальній кімнаті Google Classroom викладач може вказати термін здачі роботи. Коли студент здає завдання до завершення терміну виконання, на його документі з’являється статус «Перегляд», що дозволяє викладачеві перевірити роботу. Після перевірки викладач може повернути завдання студенту для доопрацювання. Воно автоматично переходить в статус «Редагування» і студент продовжує роботу над документом. Крім того, є можливість запланувати публікацію завдання на потрібну дату і час використовуючи опцію «Запланувати». За виконанням завдань можна спостерігати і контролювати роботу над окремим завданням відразу в декількох класах. Оцінювання можна виконувати вручну або автоматизовано, наприклад використовуючи додаток Flubaroo. Система оцінювання може бути адаптована під будь-яку кількість балів (автома- 
тично 100 балів). Після оцінювання за допомогою кнопки «Повернути» оцінка відправляється на пошту кожного учня, хоча за необхідності можна змінити оцінку. Також $є$ можливість експортувати всі оцінки курсу до таблиці. Після виставлення оцінки викладачем кожному студенту на почту прийде повідомлення. Зведені оцінки робіт студентів відображаються в закладці Оцінки (рис. 3).

Нині інтерфейс програми оптимізований для коректної роботи на мобільних пристроях, тому студенти використовують усі можливості навчатися у будь-якому місці та будь-коли: у транспорті дорогою до/з університету, у кафе, удома, чи просто йдучи містом та слухаючи запис через навушники. Можна не лише слухати, а й одночасно читати текст з екрану смартфона.

Висновки. Результати проведеного дослідження дозволяють зробити такі висновки:
Google Classroom створює реальні можливості підвищення професійної підготовки молоді; допомагає ефективніше використовувати особистий час як викладача, так і студента. Сервіс Google Classroom можна успішно використовувати для вивчення любого предмету.

Застосування сервісу Google Classroom змінюе і підхід викладача до викладання дисципліни, змушуючи його працювати творчо, бути завжди онлайн для комунікації зі студентами.

Перспективи подальших досліджень вбачаємо у детальному вивчені дистанційного навчання та самоосвіти; шляхів та умов ефективної реалізації моделей змішаного навчання у відповідності до потреб 3ВО; змін та оновлень сервісу Google Classroom $з$ метою його застосування у процесі підготовки конкурентоспроможного майбутнього фахівця.

\section{СПИСОК ВИКОРИСТАНИХ ДЖЕРЕЛ}

1. Ігнатенко О. Електронні освітні ресурси як невід’ємна складова освітнього процесу / Олена Ігнатенко, Віта Перевозник / Освіта. Технікуми, коледжі: навчально-методичний журнал. Київ: Науково-методичний центр аграрної освіти, 2016. № 3/4. С. 15-18

2. Кадемія М. Ю. Інформаційно-комунікаційні технології навчання : термінологічний словник. Львів : Вид-во «СПОЛОМ», 2009. $260 \mathrm{c}$.

3. Карєвік О.О. 3 досвіду впровадження технології дистанційного навчання в економічній освіті сучасної України [Текст] / Карєвік О.О., Шалімова Л.М., Руднєва І.М. // Сборник научных трудов «Вестник НТУ «ХПИ»: Технічний прогрес та ефективність виробництва. 2010. № 8. С. 71-78.

4. Ковальська К. Р. Дистанційне навчання як перспективна форма розвитку предметно-орієнто ваних професійних компетентностей учителів. http://www. nbuv.gov.ua/e-journals/.

5. Морзе Н. В. Критерії якості електронних навчальних курсів, розроблених на базі платформ дистанційного навчання. / Н. В. Морзе, О. Г. Глазунова / [Електронний ресурс]. Інформаційні технологї̈ в освіті. 2009. № 4. С. 63-76. URL: http://ite.kspu.edu/issue-13/p-63-75 (дата звернення: 01.11.2018)

6. Організація дистанційного навчання. Створення електронних навчальних курсів та електронних тестів: навч. посібн. / В.В. Вишнівський, М.П. Гніденко, Г.І. Гайдур, О.О. Ільїн. К. : ДУТ, 2014. 140 с.

7. Полат Е.С. Новые педагогические и информационные технологии в системе образования : учебн. пособ. для студ. педаг. вузов и системы повышения квалификации педаг. кадров / Е.С. Полат, М.Ю. Бухаркина, М.Ю. Моисеева, А.Е. Петров. - М.: Академия, 2000. - 272 с.

8. Ржевський Г.М. Дистанційна форма навчання в сучасних умовах: психолого-педагогічні особливості / Г.М. Ржевський. Науковий вісник Національного університету. Вип. 259. 2017. С. 214-221

9. Ткачук В. В. Створення електронних навчально-методичних комплексів у мобільно орієнтованому середовищі навчання ВНЗ / В. В. Ткачук, С. О. Семеріков, Ю. В. Счкало / Новітні комп'ютерні технології. Кривий Ріг : Видавничий центр ДВНЗ «Криворізький національний університет», 2017. Том XV. 281 с.

10. Толочко В. М. Проблемні аспекти дистанційної форми освіти та можливості іiі використання в Україні / B. М. Толочко / [Електронний ресурс]. - Режим доступу: http://www.provisor.com.ua/archive/2009/N11/padfo_119.php.

11. Хатаева Р.С. Подготовка преподавателя к профессиональной деятельности в условиях информатизации образования. Информатика и образование. № 6. 2014. С. 79-81.

12. Шевчук Б.В. Психолого-педагогічні аспекти організації інформаційної взаємодії в умовах використання комп'ютерно-орієнтованих засобів навчання. Науковий вісник Ужгородського університету. Серія: "Педагогіка. Сочіальна робота». 2017. Випуск 3 (42). С. 71-82.

\section{REFERENCES}

1. Ihnatenko O. Elektronni osvitni resursy yak nevidiemna skladova osvitnoho protsesu [Electronic educational resources as an integral part of the educational process]. / Olena Ignatenko, Vita Perevoznik / Education. Technical schools, colleges: educational and methodical magazine. Kyiv: Scientific and Methodological Center for Agrarian Education. $2016 . \mathrm{Nr} 3 / 4$. pp. 15-18 [in Ukrainian].

2. Kademiia M. Yu. Informatsiino-komunikatsiini tekhnolohii navchannia : terminolohichnyi slovnyk [Information and communication technologies of teaching: terminological dictionary]. Lviv : Vyd. "SPOLOM", 2009. 260 p. [in Ukrainian].

3. Karievik O.O. Z dosvidu vprovadzhennia tekhnolohii dystantsiinoho navchannia v ekonomichnii osviti suchasnoi Ukrainy [From the experience of introducing distance learning technology in economic education of modern Ukraine]. / 
O.O. Karievik, L.M.Shalimova, I.M. Rudnieva / Sbornyk nauchnыkh trudov "Vestnyk NTU "KhPY": Tekhnichnyi prohres ta efektyvnist vyrobnytstva. 2010. Nr 8. pp. 71-78 [in Ukrainian].

4. Kovalska K. R. Dystantsiine navchannia yak perspektyvna forma rozvytku predmetno-oriiento vanykh profesiinykh kompetentnostei uchyteliv. [Distance learning as a promising form of development of subject-oriented professional competencies of teachers]. URL: http://www. nbuv.gov.ua/e-journals/.

5. Morze N. V., Hlazunova O. H. Kryterii yakosti elektronnykh navchalnykh kursiv, rozroblenykh na bazi platform dystantsiinoho navchannia. [Quality criteria for e-learning courses developed on the basis of distance learning platforms.]. / N. V. Morze, O. H. Hlazunova / [Elektronnyi resurs]. Informatsiini tekhnolohii v osviti. 2009. Nr 4. pp. 63-76., URL: http://ite.kspu.edu/issue-13/p-63-75 (data zvernennia: 01.11.2020) [in Ukrainian].

6. Orhanizatsiia dystantsiinoho navchannia. Stvorennia elektronnykh navchalnykh kursiv ta elektronnykh testiv: navch. posibn.[ Organization of distance learning. Creation of electronic training courses and electronic tests] / V.V. Vyshnivskyi, M.P. Hnidenko, H.I. Haidur, O.O. Ilin. K. : DUT, 2014. 140 p. [in Ukrainian].

7. Polat E.S. Novye pedagogicheskie i informacionnye tehnologii v sisteme obrazovanija [New pedagogical and information technologies in the education system]: uchebn. posob. dlja stud. pedag. vuzov i sistemy povyshenija kvalifikacii pedag. Kadrov / E.S. Polat, M.Ju. Buharkina, M.Ju. Moiseeva, A.E. Petrov. M.: Akademija, 2000. 272 p. [in Russian].

8. Rzhevskyi H.M. Dystantsiina forma navchannia v suchasnykh umovakh: psykholoho-pedahohichni osoblyvosti [Distance learning in modern conditions: psychological and pedagogical features]. Naukovyi visnyk Natsionalnoho universytetu, Vyp. 259. 2017. pp. 214-221 [in Ukrainian].

9. Tkachuk V. V. Stvorennia elektronnykh navchalno-metodychnykh kompleksiv u mobilno oriientovanomu seredovyshchi navchannia VNZ [Creation of electronic educational and methodical complexes in a mobile-oriented university learning environment] / V. V. Tkachuk, S. O. Semerikov, Yu. V. Yechkalo / Novitni kompiuterni tekhnolohii. Kryvyi Rih : Vydavnychyi tsentr DVNZ «Kryvorizkyi natsionalnyi universytet». 2017. Tom XV. 281 p. [in Ukrainian].

10. Tolochko V. M. Problemni aspekty dystantsiinoi formy osvity ta mozhlyvosti yii vykorystannia v Ukraini [Problematic aspects of distance education and possibilities of its use in Ukraine]. URL: http://www.provisor.com.ua/archive /2009/N11/ padfo_119.php.

11. Hataeva R.S. Podgotovka prepodavatelja k professional'noj dejatel'nosti v uslovijah informatizacii obrazovanija [Preparing a teacher for professional activity in the context of informatization of education]. Informatika $i$ obrazovanie. Nr 6. 2014. pp. 79-81. [in Russian].

12. Shevchuk B.V. Psykholoho-pedahohichni aspekty orhanizatsii informatsiinoi vzaiemodii v umovakh vykorystannia kompiuterno-oriientovanykh zasobiv navchannia [Psychological and pedagogical aspects of the organization of information interaction in the conditions of use of computer-oriented teaching aids]. Naukovyi visnyk Uzhhorodskoho universytetu. Seriia: «Pedahohika. Sotsialna robota». Vypusk 3 (42). 2017. pp. 71-82. [in Ukrainian]. 